\title{
TEKNOLOGI PENGERING PADI UNTUK KETAHANAN PANGAN DI DESA WRINGIN PUTIH, BANYUWANGI
}

\author{
IGNB. Catrawedarmaํㅜ Zulis Erwanto², Danang Sudarso WPJW³, Akhmad Afandi ${ }^{4}$ \\ 1 Program Studi Teknik Mesin Politeknik Negeri Banyuwangi \\ Email : ignb.catrawedarma@poliwangi.ac.id \\ 2Program Studi Teknik Sipil, Politeknik Negeri Banyuwangi \\ Email : zulis.erwanto@poliwangi.ac.id \\ 3Program Studi Agribisnis Politeknik Negeri Banyuwangi \\ Email : danang.sudarso.poliwangi@gmail.com \\ ${ }^{4}$ Program Studi Teknik Mesin Politeknik Negeri Banyuwangi \\ Email : fandi@poliwangi.ac.id
}

\begin{abstract}
ABSTRAK
Desa Wringin Putih merupakan salah satu desa di Kabupaten Banyuwangi yang mengalami permasalahan dalam penanganan pasca panen padi. Selama ini penanganan yang dilakukan adalah dengan mengeringkan padi dibawah sinar matahari, cara ini terkendala disaat musim hujan, sehingga tidak bisa melakukan pengeringan. Jika proses ini terlambat, maka mengganggu tingkat kestabilan produktivitas beras dan pasokan beras ke masyarakat menjadi terlambat sehingga pada akhirnya mengganggu ketahanan pangan. Pengering dengan konsep natural convection menjadi salah satu solusi untuk membantu petani dalam meningkatkan nilai jual gabahnya. Pada prinsipnya pengering ini akan mengurangi kadar air secara perlahan-lahan karena udara panas secara alami mengalir kedalam ruang pengering tanpa bantuan blower mirip dengan pengering sinar matahari tetapi tidak perlu ruang yang luas, disamping itu kontaminasi oleh debu dan kotoran dapat dihindari. Berdasarkan hasil sosialisasi dan workshop alat pengering yang dilakukan di desa Wringin Putih didapatkan bahwa penerapan teknologi pengering sangat membantu petani dalam penanganan pasca panen khusunya dimusim hujan. Prototipe alat pengering ini dirancang dengan konsep yang sederhana untuk dapat dibuat dalam skala rumah tangga. Bed pengeringnya dengan diameter $60 \mathrm{~cm}$ dan lebar $30 \mathrm{~cm}$, serta menggunakan motor listrik dengan daya 1 HP. Diharapkan dengan adanya penerapan teknologi pengering ini dapat membantu penanganan pasca panen dari petani di desa wringin putih.
\end{abstract}

Keywords- Padi, Natural Convection Dryer

\section{PENDAHULUAN}

Pada data di BPS bahwa produktivitas padi di Kabupaten Banyuwangi mengalami ketidakstabilan dari tahun 2013 sampai 2015. Jumlah produksi padi tahun 2013 sebanyak 760.824 ton, 777.996 ton tahun 2014 dan 899.880 ton tahun 2015. Produktivitas padi tahun 2013 sebesar 65,87Kw/Ha, tahun 2014 sebesar 64,94 Kw/Ha, dan tahun 2015 sebesar $65,83 \mathrm{Kw} / \mathrm{Ha}$. Dengan produksi yang meningkat dari tahun 2013 sampai 2015, seharusnya produktifitas padi mengalami peningkatan, tetapi terjadi penurunan pada tahun 2014. Hal ini menjadi indikator ketidakstabilan produktivitas padi. Ketidakstabilan produktivitas padi yang dapat mempengaruhi ketahanan pangan salah satunya disebabkan oleh kehilangan hasil pada saat pengeringan sebesar 2,13\%.

Proses pengeringan yang selama ini dilakukan dengan mengeringkan dibawah sinar matahari. Cara ini terkendala disaat musim hujan, sehingga tidak bisa melakukan pengeringan. Jika proses ini terlambat, maka mengganggu tingkat kestabilan produktivitas beras dan pasokan beras ke masyarakat menjadi terlambat sehingga pada akhirnya mengganggu ketahanan pangan.

Pengering dengan konsep natural convection menjadi salah satu solusi untuk membantu 
petani dalam meningkatkan nilai jual gabahnya. Pada prinsipnya pengering ini akan mengurangi kadar air secara perlahan-lahan karena udara panas secara alami mengalir kedalam ruang pengering tanpa bantuan blower mirip dengan pengering sinar matahari tetapi tidak perlu ruang yang luas, disamping itu kontaminasi oleh debu dan kotoran dapat dihindari.

Berdasarkan beberapa permasalahan dan teknologi yang diuraikan diatas, maka melalui program diseminasi produk teknologi ini dilakukan penerapan teknologi pengering bekerjasama dengan kelompok tani di Desa Wringin Putih, Banyuwangi yang sebagian besar mata pencaharian masyarakatnya sebagai petani sawah. Maka dari itulah melalui program ini diharapkan dapat meningkatkan produktivitas beras sebagai wujud ketahanan pangan.

\section{TARGET DAN LUARAN}

Diseminasi produk teknologi ke masyarakat bertujuan membantu memecahkan permasalahan yang dihadapi oleh petani untuk meningkatkan produktivitas beras sebagai wujud ketahanan pangan.

Sasaran program ini adalah para petani atau kelompok tani yang ada di Desa Wringin Putih, Kecamatan Muncar, Kabupaten Banyuwangi.

Target luaran dalam program diseminasi produk teknologi ke mitra adalah berupa rancang bangun alat pengering padi "Natural Convection Dryer" di Desa Wringin Putih, Kecamatan Muncar, Kabupaten Banyuwangi.

Tabel I. Target Capaian Luaran

\begin{tabular}{|c|l|l|}
\hline No & \multicolumn{1}{|c|}{ Jenis Luaran } & \multicolumn{1}{|c|}{$\begin{array}{c}\text { Indikator } \\
\text { Capaian }\end{array}$} \\
\hline 1 & $\begin{array}{l}\text { Publikasi ilmiah di } \\
\text { jurnal/prosiding }\end{array}$ & Submitted \\
\hline 2 & $\begin{array}{l}\text { Publikasi pada media } \\
\text { massa } \\
\text { (cetak/elektronik) }\end{array}$ & Sudah terbit \\
\hline 3 & $\begin{array}{l}\text { Peningkatan omzet pada } \\
\text { mitra yang bergerak } \\
\text { dalam bidang ekonomi }\end{array}$ & Tidak ada \\
\hline 4 & $\begin{array}{l}\text { Peningkatan kuantitas } \\
\text { dan kualitas produk }\end{array}$ & Ada \\
\hline 5 & Peningkatan & Tidak ada \\
\hline
\end{tabular}

\begin{tabular}{|c|l|l|}
\hline & $\begin{array}{l}\text { pemahaman dan } \\
\text { ketrampilan masyarakat }\end{array}$ & Tidak ada \\
\hline 6 & $\begin{array}{l}\text { Peningkatan } \\
\text { ketentraman/kesehatan } \\
\text { masyarakat (mitra } \\
\text { masyarakat umum) }\end{array}$ & Produk \\
\hline 7 & $\begin{array}{l}\text { Jasa, model, rekayasa } \\
\text { sosial, sistem, } \\
\text { produk/barang }\end{array}$ & Tidak ada \\
\hline 8 & $\begin{array}{l}\text { Hak kekayaan } \\
\text { intelektual (paten, paten } \\
\text { sederhana, hak cipta, } \\
\text { merek dagang, rahasia } \\
\text { dagang, desain produk } \\
\text { industri, perlindungan } \\
\text { varietas tanaman, } \\
\text { perlindungan topografi. }\end{array}$ & \\
\hline 9 & Buku Ajar & Tidak ada \\
\hline
\end{tabular}

Sumber : Hasil Analisis, 2017

\section{METODE PELAKSANAAN}

Dalam pelaksanaan program ini, metode pelaksanaan yang digunakan didasari dari permasalahan yang ada di Desa Wringin Putih, Kecamatan Muncar, Banyuwangi yaitu mengatasi permasalahan produktivitas gabah kering dengan merancang bangun alat pengering padi "Natural Convection Dryer" melalui beberapa tahapan yaitu:

1. Kegiatan sosialisasi kegiatan diseminasi produk teknologi

2. Persiapan alat dan bahan yang dibutuhkan

3. Perencanaan desain rangka

4. Perakitan dan Finishing

5. Workshop pengoperasian alat

6. Monitoring dan Evaluasi Indikator Keberhasilan Program

7. Publikasi

8. Pelaporan Akhir

Kegiatan ini difokuskan pada workshop pengoperasian alat, dengan maksud agar masyarakat di desa Wringin Putih memahami cara pengoperasian dan juga cara perawatan alat sehingga pada akhirnya nanti para petani bisa menggunakan alat pengering tersebut sesuai dengan Standar Operasional Prosedurnya untuk memperkecil terjadinya kecelakaan kerja. 
Bentuk desain dari alat pengeringnya dapat dilihat pada Gambar 1.

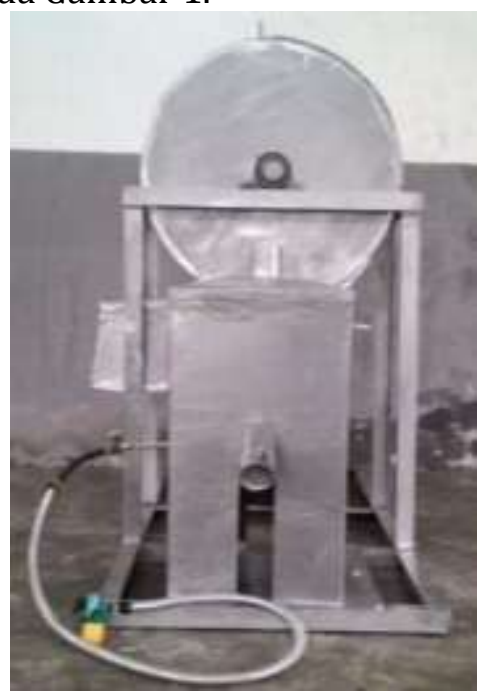

Gambar 1. Gambar Desain Alat Pengering (Hasil Desain, 2016)

\section{KELAYAKAN PERGURUAN TINGGI}

P3M (Pusat Penelitian Dan Pengabdian Kepada Masyarakat) Politeknik Negeri Banyuwangi telah beberapa kali ikut berperan aktif dalam program pengabdian kepada masyarakat seperti berikut.

1. IbM Kelurahan Sobo dalam Pemberdayaan Ibu-ibu rumah Tangga Non Produktif

2. IbM Desa Purwodadi Kecamatan Gambiran Melalui Rancang Bangun Pembangkit Listrik Tenaga Matahari (PLTM) Sebagai Upaya Peningkatan Frekuensi Produksi Hasil Panen Tanaman Buah Naga Merah

3. IbM Desa Tulikup Dalam Upaya Meningkatkan Produktivitas Usaha Batu Bata Bali

4. IbM Kelompok Pengguna Air Bersih Desa Pakel Melalui Teknologi Filter Beton Pasir

5. Pemanfaatan Teknologi Tepat Guna Pembuatan Briket Limbah Kotoran Ternak Ruminansia

6. IbM Peningkatan Daya Saing Produk Madu Desa Taman Sari Kabupaten Banyuwangi

7. IbM Pemberdayaan Kelompok Ternak Kambing Etawa Melalui Pelatihan Dan Pendampingan Dalam Produksi Silase Sebagai Pakan Ternak Alternatif Di Desa Wongsorejo

8. Rancang Bangun Mesin Pembelah Juring Bambu Untuk Meningkatkan Produktifitas UMKM Penghasil Tempat Ikan Pindang Desa Blambangan Kecamatan Muncar
9. IbM Mesin Pencetak Pellet Ikan Lele Di Desa Kedungrejo Kecamatan Muncar

10. IbM Puskesmas Kecamatan Licin Melalui Pembuatan Dan Pelatihan Sistem Monitoring Emosional Pasien Berbasis Java

11. IbM Penerapan Teknologi Tepat Guna Mesin Penghalus Kotoran Kambing Untuk Pupuk Organik Tanaman Jeruk

12. IbM Penyuluhan Dan Pelatihan Sistem Tanam Padi 454 Kelompok Tani Sumber Urip Desa Watu Kebo

\section{HASIL DAN LUARAN YANG DICAPAI}

Sebelum dilakukan penerapan teknologi pengering di Desa Wringin Putih, terlebih dahulu dilakukan survey kondisi penanganan pasca panen padi dan jagung. Dua komoditi tersebut dilakukan survey karena padi menjadi kebutuhan pokok dan jagung digunakan untuk musim tanam setelah panen padi. Selama ini proses penanganan pasca panen kedua komoditi tersebut hanya dengan cara manual yaitu dikeringkan dibawah sinar matahari. Proses pengeringan ini memiliki beberapa kendala yaitu butuh tempat yang luas, hanya bisa dilakukan dimusim kemarau, dan padi dapat terkontaminasi oleh debu dan kotoran. Disamping itu, proses pengeringan yang selama ini dilakukan mengurangi hasil gabah 2-3 persen. Padahal, proses pengeringan yang baik bisa meningkatkan harga jual Gabah sebesar 12 persen dari rata-rata harga jual sebesar $\mathrm{Rp}$. 4.347. Kendala Petani berupa perubahan siklus hujan, berpotensi kehilangan berat pada pengeringan dan kehilangan kualitas dan harga gabah terbaik. Dalam skala luas, tentu kondisi ini mempengaruhi produktivitas beras Banyuwangi dan pasokan beras ke masyarakat. Oleh karena itu, dilakukanlah program diseminasi produk teknologi ke kelompok tani di Desa Wringin Putih melalui penerapan teknologi pengering padi dan jagung.

Dalam proses pelaksanaan program ini terlebih dahulu dilakukan sosialisasi tentang pentingnya program diseminasi ini bagi 
masyarakat dan juga pentingnya hilirisasi teknologi ke masyarakat. Dalam rangkaian sosialisasi ini juga digali pemikiran-pemikiran kritis dari masyarakat petani yang langsung berkecimpung dalam usaha pertanian untuk mengkritisi teknologi pengering yang akan diterapkan seperti tampak pada Gambar 2 saat foto bersama dalam acara sosialisasi program kerja.

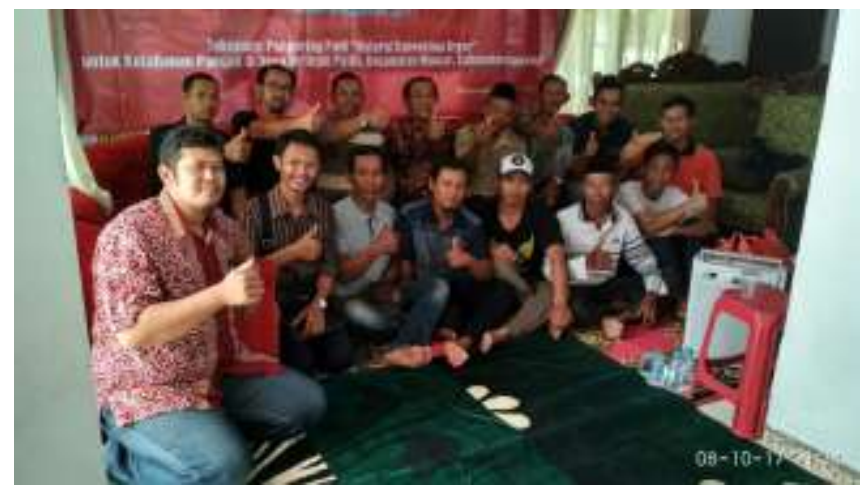

Gambar 2. Sosialisasi Program di Desa Wringin Putih

Proses perencanaan dan perancangan ini dilakukan di Workshop Teknik Mesin Politeknik Negeri Banyuwangi. Dari hasil perancangan dengan ukuran diameter bed pengering $60 \mathrm{~cm}$ dan lebar $30 \mathrm{~cm}$ didapat kapasitas prototype adalah $50 \mathrm{~kg}$ dengan menggunakan bahan bakar LPG dan sudah dilengkapi alat pengaduk, sehingga tidak perlu mengaduk secara manual seperti yang biasa dilakukan dalam proses pengeringan konvensional. Alat pengaduk ini digerakkan oleh motor listrik 1 HP seperti terlihat pada Gambar 3. Dari proses uji coba dalam sekali proses alat pengering ini akan mengeringkan gabah dalam waktu 6-8 jam untuk mendapatkan kadar air 12-14\%. Setelah proses perancangan dan uji coba, dilakukan serah terima alat untuk mitra tani di Desa Wringin Putih.

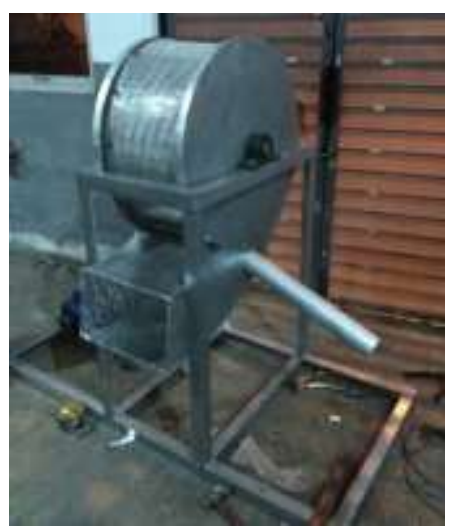

Gambar 3. Proses Perancangan

Sebelum proses serah terima alat, dilakukan workshop tentang cara perancangan, cara pengoperasian, dan cara perawatan alat pengering tersebut seperti terlihat pada Gambar 4. Proses perancangan alat ini sangat mudah karena dapat dibongkar pasang sehingga memudahkan petani untuk membuat replika dari alat ini. Proses perancangan pertama kali dilakukan pembuatan rangka penopang bed pengering. Setelah itu, merangkai bed pengering dan memasangnya pada rangkat. Langkah selanjutnya adalah memasang motor penggerak, gear box, dan bagian transmisi yang lainnya. Langkah terakhir adalah melakukan finishing pada bagian-bagian yang dianggap perlu.

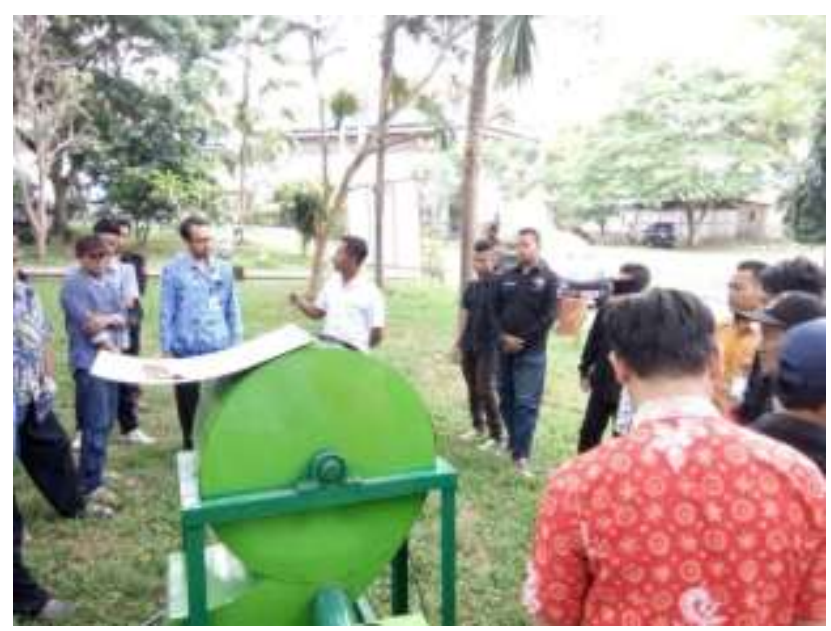

Gambar 4. Workshop Operasional Alat

Standar operasional prosedur alat pengering ini adalah memastikan bahwa seluruh aliran listrik sudah dimatikan, menutup rapat saluran 
keluar gabah, membuka saluran masuk gabah, memasukkan gabah, menutup saluran masuk gabah, menyalakan motor listrik (untuk memutar bed pengering), menyalakan kompor (untuk memanaskan saluran masuk udara pengering). Setelah 6-8 jam, dilakukan pengamatan terhadap tekstur beras dengan cara mematahkan butiran gabah. Cara pengamatan ini masih manual, kedepan akan ditambahkan alat untuk mendeteksi kadar air gabah sehingga tidak perlu dilakukan secara manual. Setelah diperkirakan kering, maka kompor dimatikan, saluran keluar gabah dibuka, dan motor listrik tetap dalam posisi ON. Setelah semua gabah keluar, dilanjutkan dengan mematikan motor listrik. Langkah selanjutnya adalah melakukan perawatan rutin dengan membersihkan bed pengering setiap saat setelah pemakaian. Disamping itu, rantai dan sistem transmisi lainnya diberi pelumas untuk mendapatkan umur pakai yang lebih lama.

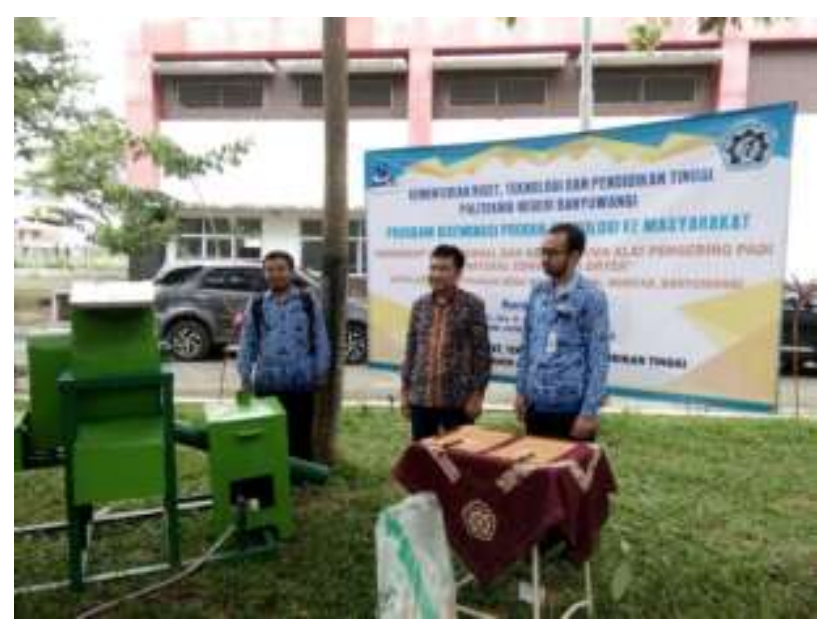

Gambar 5. Serah Terima Alat

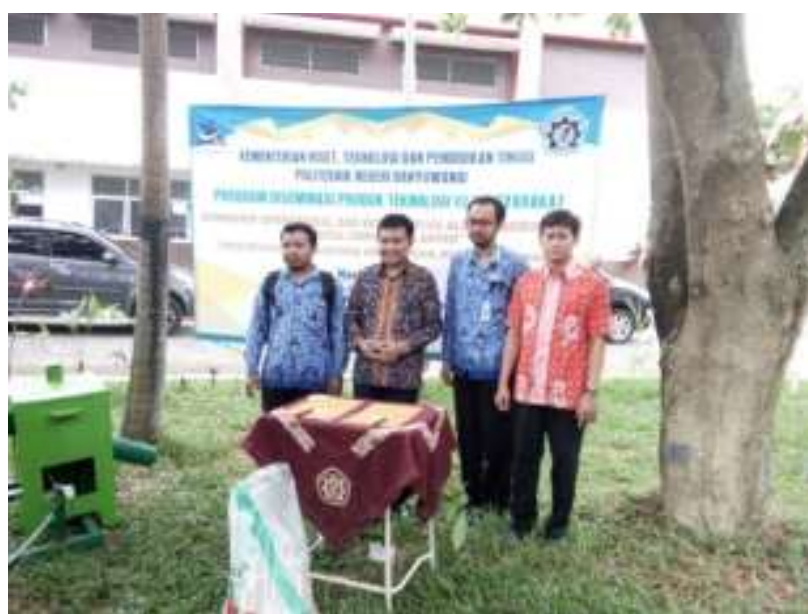

Gambar 6. Serah Terima Alat Ke Mitra

Proses serah terima alat dilakukan setelah workshop dengan penandatanganan dokumen serah terima dengan disaksikan oleh anggota DPR RI Komisi X Bidang Pendidikan oleh Bapak Drs. H. Anas Thahir, MBA. Seperti pada Gambar 5. Sedangkan dokumen serah terima alat Diseminasi Produk Teknologi diserahkan ke Mitra bersama Alatnya kepada Bapak Yoga Ananta Budiman dari Koordinator atau perwakilan kelompok Tani Makmur dari Desa Wringin Putih, Kecamatan Muncar, Kabupaten Banyuwangi seperti terlihat pada Gambar 6. Dari proses serah terima ini diharapkan kepada kelompok tani untuk selalu merawat dan menjaga alat pengering ini agar tetap dalam kondisi siap untuk digunakan kapan pun dan dimana pun. Disamping itu, dari serah terima alat ini diharapkan juga dapat meningkatkan nilai jual padi maupun jagung yang dihasilkan oleh petani yang pada akhirnya nanti dapat meningkatkan produktivitas beras sebagai wujud ketahanan pangan.

\section{KESIMPULAN DAN SARAN}

1. Berdasarkan hasil sosialisasi dan workshop alat pengering yang dilakukan di desa Wringin Putih didapatkan bahwa penerapan teknologi pengering sangat membantu petani dalam penanganan pasca panen khusunya dimusim hujan.

2. Prototipe alat pengering ini dirancang dengan konsep yang sederhana untuk dapat dibuat dalam skala rumah tangga. Bed pengeringnya 
dengan diameter $60 \mathrm{~cm}$ dan lebar $30 \mathrm{~cm}$, serta menggunakan motor listrik dengan daya $1 \mathrm{HP}$.

3. Luaran yang dicapai adalah peningkatan pemahaman petani tentang teknologi pengering untuk penanganan padi pasca panen. Selain itu juga publikasi melalui jurnal nasional dan media cetak dan menghasilkan produk prototype alat pengering gabah.

Beberapa saran dalam program Diseminasi Produk Teknologi di Desa Wringin Putih, Kec. Muncar, Kab. Banyuwangi antara lain :

1. Perlu adanya rekonstruksi desain alat pengering dalam kapasitas besar.

2. Perlu ditambahkan teknologi kontrol otomatis untuk mendeteksi kadar air gabah, sehingga tidak dilakukan secara manual.

3. Perlu pemeliharaan alat secara rutin agar bisa selalu terpelihara dan terawat dengan baik.

\section{UCAPAN TERIMAKASIH}

Kegiatan ini terselenggara atas peran serta dari 3 lembaga yaitu Direktorat Riset dan Pengabdian Masyarakat (DRPM), Kemenristekdikti, Politeknik Negeri Banyuwangi (Poliwangi), dan Kelompok Tani di Desa Wringin Putih.. DRPM selaku pendukung dana, Poliwangi selaku pelaksana program desiminasi teknologi dan kelompok tani selaku mitra dalam program ini. Disamping itu, kegiatan ini juga didukung oleh Bpk Drs. H. Anas Thahir, MBA (Anggota Komisi X DPR RI Bidang Pendidikan). Oleh karena itu, dalam kesempatan ini disampaikan ucapan terimakasih yang sebesar-besarnya atas bantuan dan dukungan untuk terselenggaranya kegiatan desiminasi teknologi ini.

\section{DAFTAR PUSTAKA}

https://banyuwangikab.bps.go.id/linkTabelStati s/view/id/90 